\title{
Climatic control on extreme sediment transfer from Dokriani Glacier during monsoon, Garhwal Himalaya (India)
}

\author{
Amit Kumar*, Akshaya Verma, Dwarika Prasad Dobhal, \\ Manish Mehta and KaPIL Kesarwani \\ Centre for Glaciology, Wadia Institute of Himalayan Geology, 33 GMS Road, Dehra Dun, India. \\ ${ }^{*}$ Corresponding author.e-mail: amithydrocoin@gmail.com amitwalia@wihg.res.in
}

In the Himalayas, most of the glaciers are covered by thick debris, especially in the ablation zone. Supraglacial debris cover might play an important role for sediment budget of the glaciated area or for the ablation of ice masses mantled in debris. During summer season, proglacial meltwater carries considerable amount of suspended sediment. The deglaciated area provides a ready source of sediment during Indian Summer Monsoon (ISM). The heavy sediment load from the glaciers affects the hydropower generation, irrigation and drinking water supply. Therefore, to understand the sediment delivery from glaciated basins, characteristics and variation of the suspended sediment concentrations in the proglacial meltwater stream, Dokriani Glacier, have been monitored during the ablation season (May-September). Suspended sediment samples were collected near the snout of Dokriani Glacier, Garhwal Himalaya, in 2010 and 2011. Results show that mean monthly suspended sediment concentrations (SSC) were 1499, 2303, 3845 and $1649 \mathrm{mg} / \mathrm{l}$ for the months June, July, August, and September, respectively, indicating highest concentration in August followed by July. Over the period of recording, daily mean suspended concentration in the melt stream varied from 13-9798.2 mg/l, which is very high, caused due to a flash flood event during the monitoring period. The mean daily suspended sediment concentration was computed to be $2196 \mathrm{mg} / \mathrm{l}$. The suspended sediment concentration begins to increase with discharge from May and reduces in September. Present study provides TRMM (Tropical Rainfall Measuring Mission) derived and field based hydro-meteorological insight about severe rainstorms during the years 2010 and 2011 in the study area, which transported large amounts of sediment.

\section{Introduction}

It is known that glaciers reduce their ice mass and mass balance changes are induced by the growing debris covered area (Azam et al. 2012; Berthier and Vincent 2012) except for Karakoram anomaly (Hewitt 2005; Gardelle et al. 2012). Debris covered glaciers are common in many mountainous regions of the world. Observed retreat of glaciers is accompanied by increased extent of debris covered area near the glacier snout (Scherler et al. 2011). Investigations of the elevation changes of ice mass indirectly suggested that debris covered area shows large lowering rates (Bolch et al. 2007; Nuimura et al. 2012). Bhambri et al. (2011) published that debris covered area in glaciers of Garhwal Himalaya are increasing at different rates (Bhagirathi basin $11.8 \%$ and Alaknanda basin 17.8\%).

The Himalayan region is geologically active and structurally unstable; natural hazards related

Keywords. Garhwal Himalaya; suspended sediment concentration; debris covered glacier. 
with climate and topographic instability are frequent. The climate of the high altitude region of the Himalaya plays a vital role in the melting of snow and glaciers, retreat or advancement of glaciers, flash floods, erosion, sediment transport, landslides, subsidence, glacial lake outburst floods (GLOF's), carbonate and silicate weathering, etc., (Haeberli and Beniston 1998; Singh et al. 2012). The important factors influencing the suspended sediment transfer from glaciated regions are the climatic variables like temperature and rainfall. Some of the major flashfloods and rainfall induced landslides in the Himalayan region over the past decade have been compiled in table 1 .

Understanding the glacier regimes is important because they are the sources of information on high-mountain meteorology and hydrology, and paleoclimatic data (Meier et al. 2003). High altitude climatology is particularly important for water storage, groundwater replenishment and flood control.

It has been observed that during summer months, snow and glacier meltwater from Himalayan glaciers, transport suspended sediment at very high rates. For the Himalayan region, runoff and sediment transportation studies for some glaciers that have been carried out during the ablation season (May-September) and peak melting season (July and August) involve both glacier melting and monsoon rainfall. The middle and lower part of basins transport large amounts of suspended sediment which cause silting of the reservoirs during this period. Therefore, meltwater and sediment transfer studies from the Himalayan glaciers have received more attention for the water resources management and hydropower development in the Himalayas (Collins 1996; Hasnain and Thayyen 1999; Bhutiyani 2000; Kumar et al. 2002; Pandey et al. 2002; Jain et al. 2003; Owen et al. 2003; Singh et al. 2003, 2005, 2010a; Haritashya et al. 2006, 2010; Ali et al. 2007).

The investigations on proglacial suspended sediment from meltwater are important for lower basin hydrology. Glaciers actively erode and transport material; meltwater transports the suspended sediment further downstream. It is well known that mountainous rivers with many glaciers in their basin have high concentrations of suspended sediment. This adversely affects hydraulic facilities, e.g., hydropower turbines. Unfortunately, there are very few reliable measurements of suspended sediment, though peak floods during melting season have been monitored or reported from the region. In this paper daily data on melt runoff and sediment concentrations of Din Gad River arising from Dokriani Glacier have been analyzed. The main objective of this study is to examine the impact of extreme events on the proglacial suspended sediment regime, as well as debris flow near the snout of Dokriani Glacier. The present study for 2010-2011

Table 1. Recent records of major flash floods and landslides in the Himalaya.

\begin{tabular}{|c|c|c|c|}
\hline Type & Date & Area & Reference \\
\hline Flash flood & August 2010 & Dokriani Glacier, Uttarakhand \} & \multirow{2}{*}{ Present study } \\
\hline Flash flood & August 2011 & Dokriani Glacier, Uttarakhand $\}$ & \\
\hline Flash flood & September 2012 & Okhimath, Uttarakhand & Rana et al. (2012) \\
\hline Cloudburst & 4-6 August 2010 & Leh, J \& K (Sabu and other streams) & Thayyen et al. (2013) \\
\hline $\begin{array}{l}\text { Rainfall induced } \\
\text { landslide }\end{array}$ & $\begin{array}{l}\text { 18-21 September } \\
2010\end{array}$ & $\begin{array}{l}\text { Uttarakhand (various places on } \\
\text { Rishikesh-Mana highway) }\end{array}$ & Sati et al. (2011) \\
\hline $\begin{array}{l}\text { Rainfall induced } \\
\text { landslide }\end{array}$ & 2009 & Munsiyari & Sarkar and Kanungo (2010) \\
\hline Flash flood & 1 August 2006 & Phyang, Igu and Leh Nalla, J \& K & Thayyen et al. (2013) \\
\hline Flash flood & June 2005 & Leh and Phyang Nalla (Ganglass), J \& K & Thayyen et al. (2013) \\
\hline $\begin{array}{l}\text { Rainfall induced } \\
\text { landslide }\end{array}$ & 2003 & Varunavat, Uttarkashi, Uttarakhand & Gupta and Bist (2004) \\
\hline Cloudburst & 16 July 2003 & Kullu, Himachal Pradesh & Mazari and Sah (2004) \\
\hline Cloudburst & 10 August 2002 & Tehri, Uttaranchal & Sah et al. (2003) \\
\hline Cloudburst & 31 August 2001 & Tehri, Uttaranchal & Naithani et al. (2002) \\
\hline Cloudburst/landslide & 16 July 2001 & Rudraprayag, Uttaranchal & Kumar et al. (2003) \\
\hline $\begin{array}{l}\text { Rainfall induced } \\
\text { landslide }\end{array}$ & 1998 & Malpa and Okhimath, Uttarakhand & Sati et al. (2006) \\
\hline High rainfall & 11-19 August 1998 & Guptkashi-Rudraprayag, Uttaranchal & Rautela and Paul (2001) \\
\hline Flash flood & 11 August 1997 & Tehsil, Himachal Pradesh & Thakur (2000) \\
\hline Landslide & 24 Febuary 1993 & Jhakri, Himachal Pradesh & Thakur (2000) \\
\hline GLOF/Flash flood & 31 July 1991 & Maling, Himachal Pradesh & Thakur (2000) \\
\hline
\end{tabular}



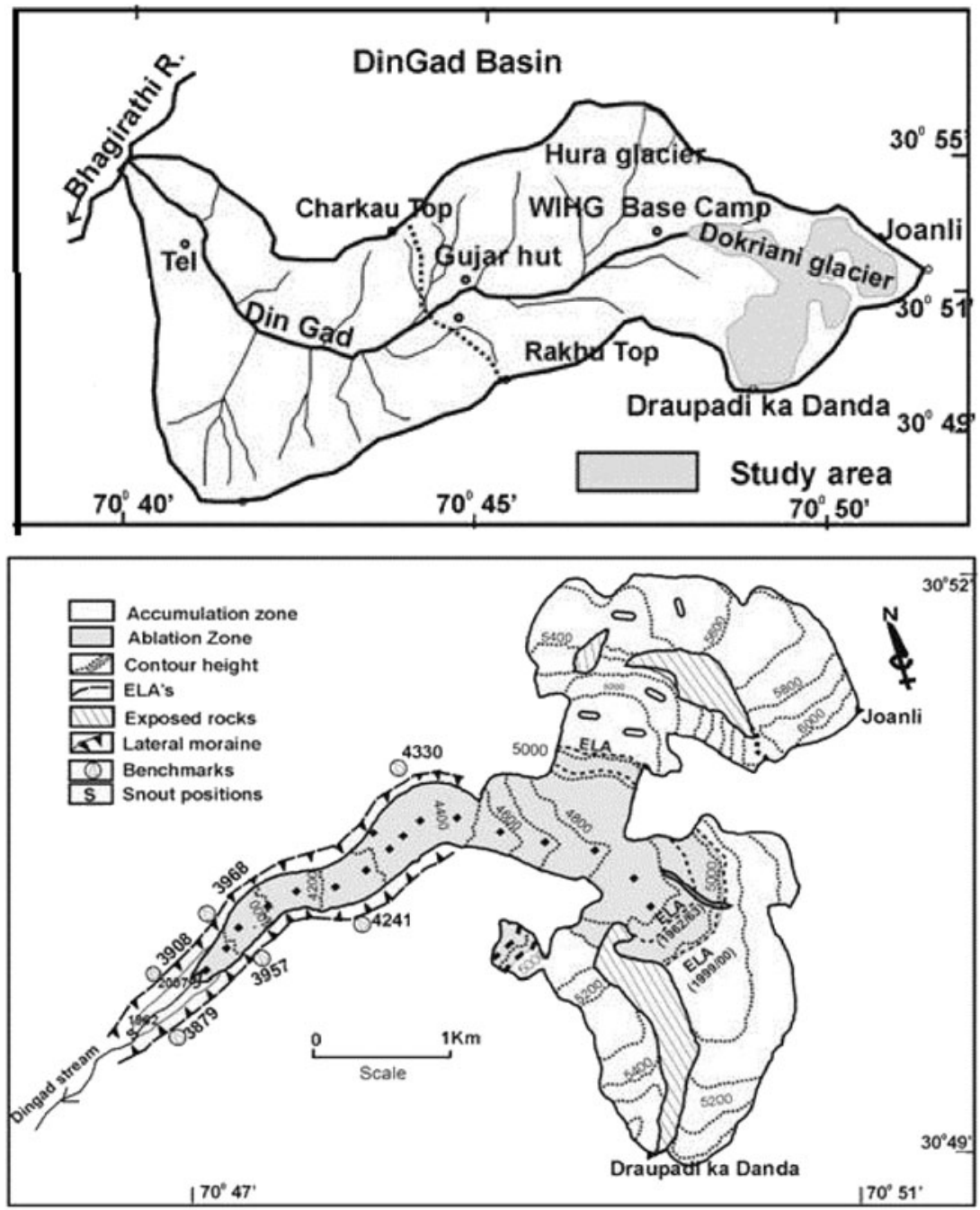

(a)

(b)

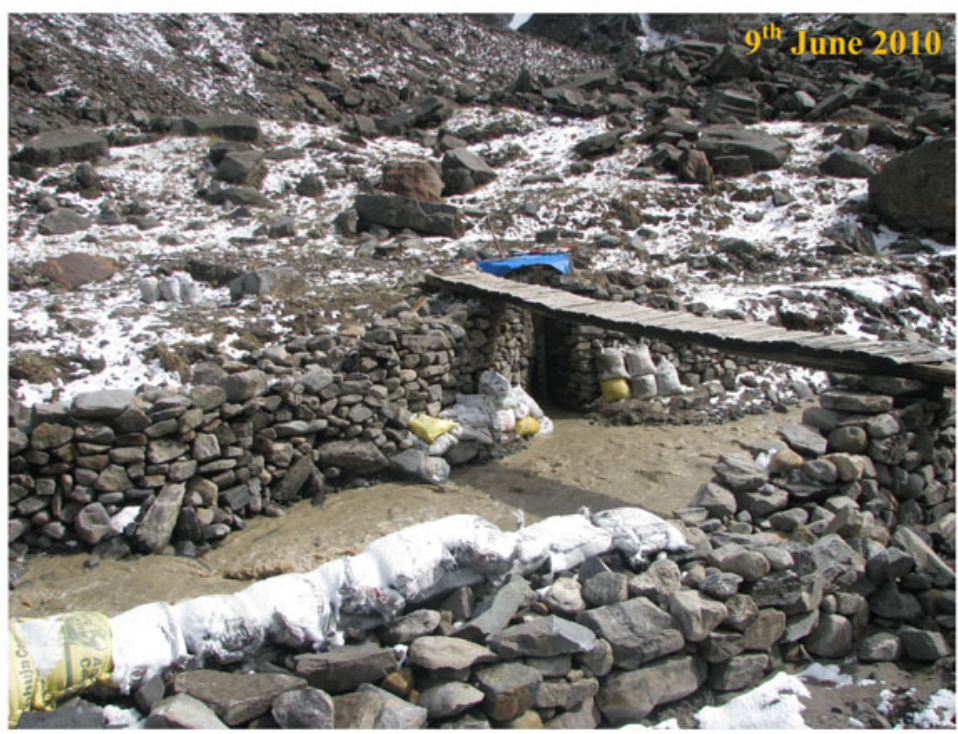

Figure 1. (a) View of the study area in Din Gad catchment located in Bhagirathi basin, Garhwal Himalaya. (b) View of the monitoring site under the bridge, meltwater flowing from Dokriani Glacier can be seen. 
has been compared with previous work at Dokriani Glacier by Singh and Ramasastri (1999) and Singh et al. $(2003,2005)$.

\section{Study area}

Dokriani Glacier is a compound valley type glacier in the Din Gad River catchment, a tributary of Bhagirathi River, Garhwal Himalaya (figure 1a). The glacier occupies an area of $7 \mathrm{~km}^{2}, 46 \%$ of the total catchment area $\left(15 \mathrm{~km}^{2}\right)$. The length of the glacier is $5.5 \mathrm{~km}$ and its elevation ranges from $3910 \mathrm{~m}$ to $6200 \mathrm{~m}$ a.s.l. The total area of accumulation and ablation zone is approximately 4.7 and $2.3 \mathrm{~km}^{2}$, respectively (Dobhal and Mehta 2010). The snout of the Dokriani Glacier is marked from where the stream Din Gad emerges. The glacier is confined to the valley region and has several avalanche zones in the accumulation and ablation areas. The glacier in its present form is bounded by left and right lateral moraines and supraglacial debris cover (figure 2).

\section{Methodology}

Meteorological observations play an important role in understanding generation mechanism of meltwater discharge from glaciers. In addition, meteorological variability is responsible for significant weather events which have affected mankind over the years. Keeping in view the importance of meteorological data observed at Himalayan glaciers, meteorological observations such as air temperature, relative humidity, precipitation, sunshine hours, wind velocity have been measured near the snout of the glacier. An existing meteorological observatory was equipped near the snout of Dokriani Glacier in the year 2009; daily rainfall was measured in a rain gauge at ground level to avoid wind effects, thermometers were used to measure maximum and minimum, dry and wet bulb temperatures and were placed at a height of $2 \mathrm{~m}$ from the ground in a Stevenson screen to avoid the effects of direct solar radiation and precipitation. A wind wane and anemometer were also installed at a height of $2 \mathrm{~m}$ above the ground in order to measure the wind velocity. The time and frequency of meteorological data collection are given in table 2. To understand temporal and spatial variability in precipitation during study period data from Tropical Rainfall Measurement Mission (TRMM) of NASA has also been used for analysis.

Hydrological data (discharge and suspended sediment) for summer (May-September) 2010 and 2011 was collected using water level data at the existing gauging site, where a bridge crosses the meltwater stream of Dokriani Glacier (figure 1b). The gauging site was repaired with the use of stone walls and sandbags along the banks of the stream such that all the meltwater flows through the channelized section. Also the large boulders transported by the stream were removed from the channel in order to get laminar flow, as far as possible. The Velocity area method was used to estimate the discharge in the river. The cross section of the stream

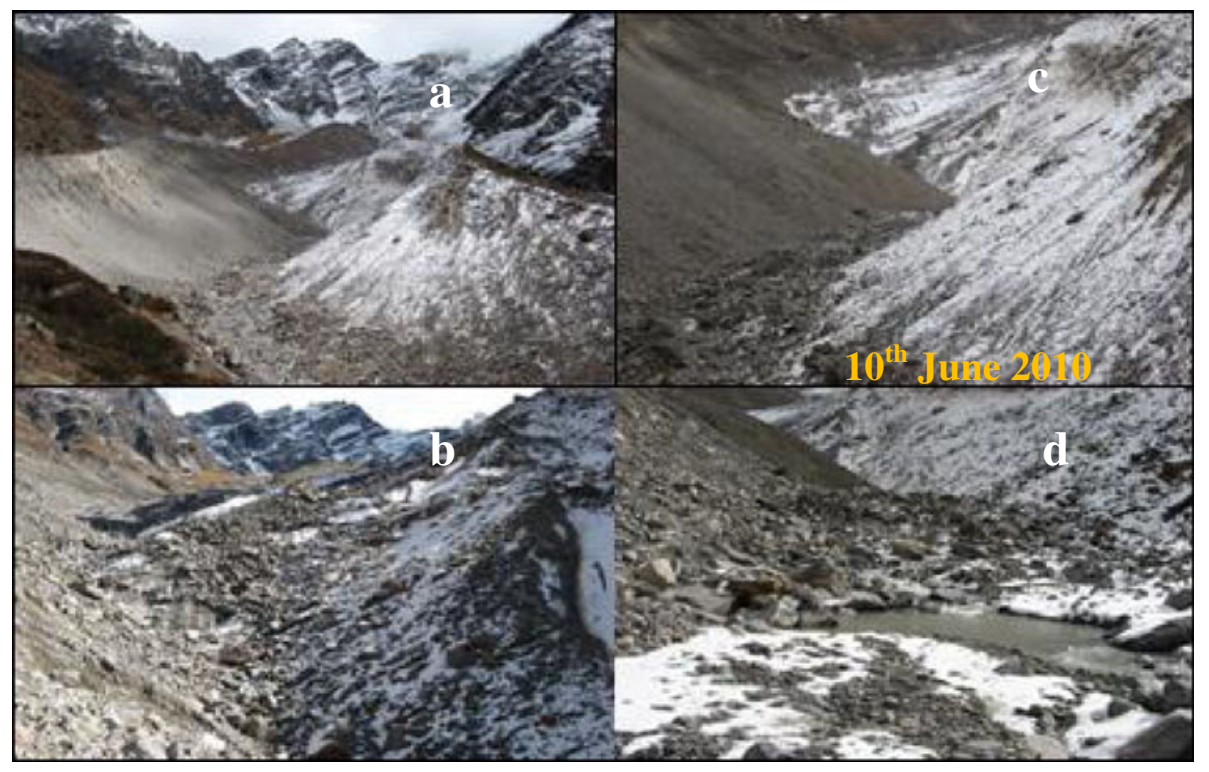

Figure 2. Features showing (a) lateral moraines, (b) snout, (c) debris avalanche, and (d) proglacial zone observed at Dokriani Glacier during the field visit in summer and winter seasons. 
Table 2. List of hydro-meteorological instruments, observations on time interval near the snout of Dokriani Glacier.

\begin{tabular}{lll}
\hline Instruments & \multicolumn{1}{c}{ Observations } & \multicolumn{1}{c}{ Time of observations } \\
\hline Manual river gauge & Water level & Hourly $(08: 00$ to $07: 00 \mathrm{hrs})$ \\
Ordinary rain gauge & Rainfall & $08: 30$ and 17:30 hrs \\
Maximum and minimum & Maximum and minimum & $08: 30 \mathrm{hrs}$ \\
$\quad$ thermometers & temperature & \\
Dry and wet bulb thermometers & Dry and wet bulb temperature & $08: 30,11: 30,14: 30,17: 30$ and $20: 30 \mathrm{hrs}$ \\
Anemometer & Wind speed & $08: 30,11: 30,14: 30,17: 30$ and $20: 30 \mathrm{hrs}$ \\
Wind wane & Wind direction & $08: 30,11: 30,14: 30,17: 30$ and $20: 30 \mathrm{hrs}$ \\
\hline
\end{tabular}
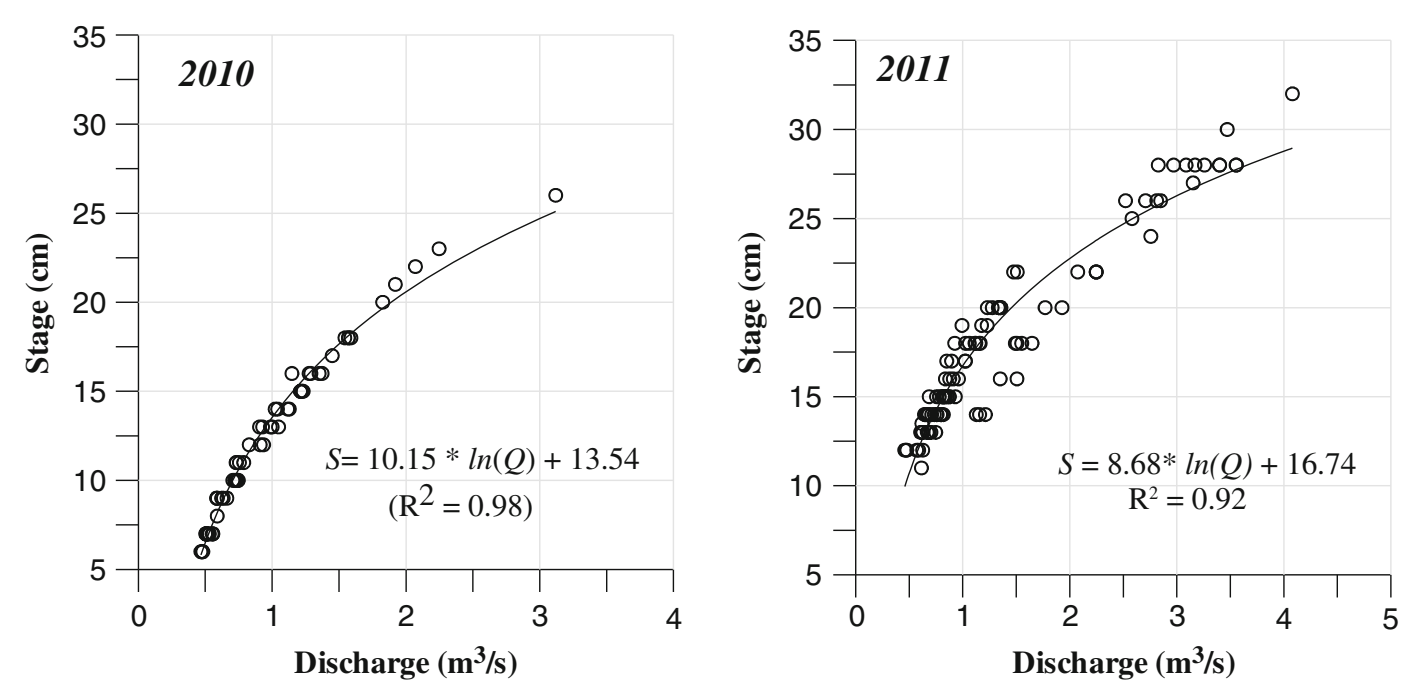

Figure 3. Stage-discharge relationship for Dokriani Glacier during ablation season 2010 and 2011.

was measured using a graduated staff from the bridge over the stream. The cross sectional area measurements were repeated throughout the melt season in order to reduce errors. A manual stage was placed in the river cross section to read the water level. Surface velocity of the stream was measured by throwing floats in the stream for a $10 \mathrm{~m}$ section and the time required to cover the distance was recorded. For accuracy in velocity, the float readings were repeated at least three times and an average value was adopted for further computations. The surface velocity was then multiplied by a constant given for Himalayan streams to calculate the mean velocity of the stream (Singh et al. 2003; Thayyen et al. 2005; Ramanathan 2011). The velocity, mean velocity and discharge were calculated as following:

$$
\begin{array}{r}
V_{s}=D / T_{d}(\mathrm{~m} / \mathrm{s}) \\
V_{m}=C \times V_{s}(\mathrm{~m} / \mathrm{s}) \\
Q=A \times V_{m}\left(\mathrm{~m}^{3} / \mathrm{s}\right),
\end{array}
$$

where $V_{s}$ is the surface velocity of the stream $(\mathrm{m} / \mathrm{s})$, $D$ is the fix distance $(\mathrm{m}), T_{d}$ is the time of travel to cover the fix distance $[D]$ by float in $\mathrm{s}, V_{m}$ is the mean velocity of the stream $(\mathrm{m} / \mathrm{s}), C$ is the constant for mountain streams $(0.85), Q$ is the discharge $\left(\mathrm{m}^{3} / \mathrm{s}\right)$, and $A$ is the cross sectional area of the stream $\left(\mathrm{m}^{2}\right)$.

Stage-discharge relationship for Dokriani Glacier has been developed to calculate discharge for the available water level records (figure 3).

$$
\begin{array}{lc}
S=10.51 * \log (Q)+13.54 & \left(R^{2}=0.98\right) \\
S=8.68 * \log (Q)+16.74 & \left(R^{2}=0.92\right)
\end{array}
$$

where $S$ is the stage or water level in $\mathrm{cm}$ and $Q$ is the discharge in $\mathrm{m}^{3} / \mathrm{s}$.

In order to estimate the suspended sediment, $500 \mathrm{ml}$ high-density polyethylene (HDPE) narrow mouth bottles were deployed to collect meltwater samples at mid depth near the centre of the stream. The samples were filtered through ash less Whattman filter paper $(0.2 \mu \mathrm{m})$ in the field and filters were packed and returned to the laboratory for weighing (Ostrem 1975; Gurnell et al. 1992; Haritashya et al. 2010). The weight of the blank filter papers was subtracted from the weight of 
filter papers containing suspended sediment. The obtained suspended sediment concentration was then converted into $\mathrm{mg} / \mathrm{l}$.

\section{Results}

Hydro-meteorological records from the Himalayan region are rare because of poor accessibility, rugged terrain, and harsh weather conditions. These records are particularly needed for long-term planning and management of water resources such as reservoir operation, irrigation, flood and runoff forecasting and hydroelectric production.

Discharge and meteorological data is the first and foremost requirement to define the hydrometeorological condition of any glacier. Meteorological data collected near the snout of Dokriani Glacier provides records for the melt season (MaySeptember) during the years 2010 and 2011. Detailed records of meteorological observations and analysis over Dokriani Glacier can be found in Singh et al. (2007).

\subsection{Precipitation $(P)$}

Precipitation is an important factor, which plays a vital role in the mobilisation of suspended sediment. It is observed that the months of August and September have maximum rainfall in the melting season. June 8 and September 16, 2010 are snowfall events that occurred during the ablation period due to drastic reduction of air temperature. Distribution of daily rainfall observed at Dokriani Glacier is shown in figure 4. Monthly rainfall measured at Dokriani Glacier were 154.40, 339.20, 427.80, 379.80 and $50.60 \mathrm{~mm}$ for 2010 and 258.9, 377.2, 610.0, 192.3 and 25.2 for 2011 in JuneOctober, respectively. Total rainfall observed at Dokriani Glacier is 1351.8 and $1463.6 \mathrm{~mm}$ during the melting season (June-September) for the years 2010 and 2011, respectively. The published data for the years 1995-1998, shows an average total rainfall of $1041.0 \mathrm{~mm}$ for the melting period as compared to $1370.0 \mathrm{~mm}$ for 2010-2011 (table 3). In order to understand the changes in the precipitation pattern we compared the rainfall intensities, which were $16.1,14.5$ and $10.4 \mathrm{~mm} / \mathrm{hr}$ for

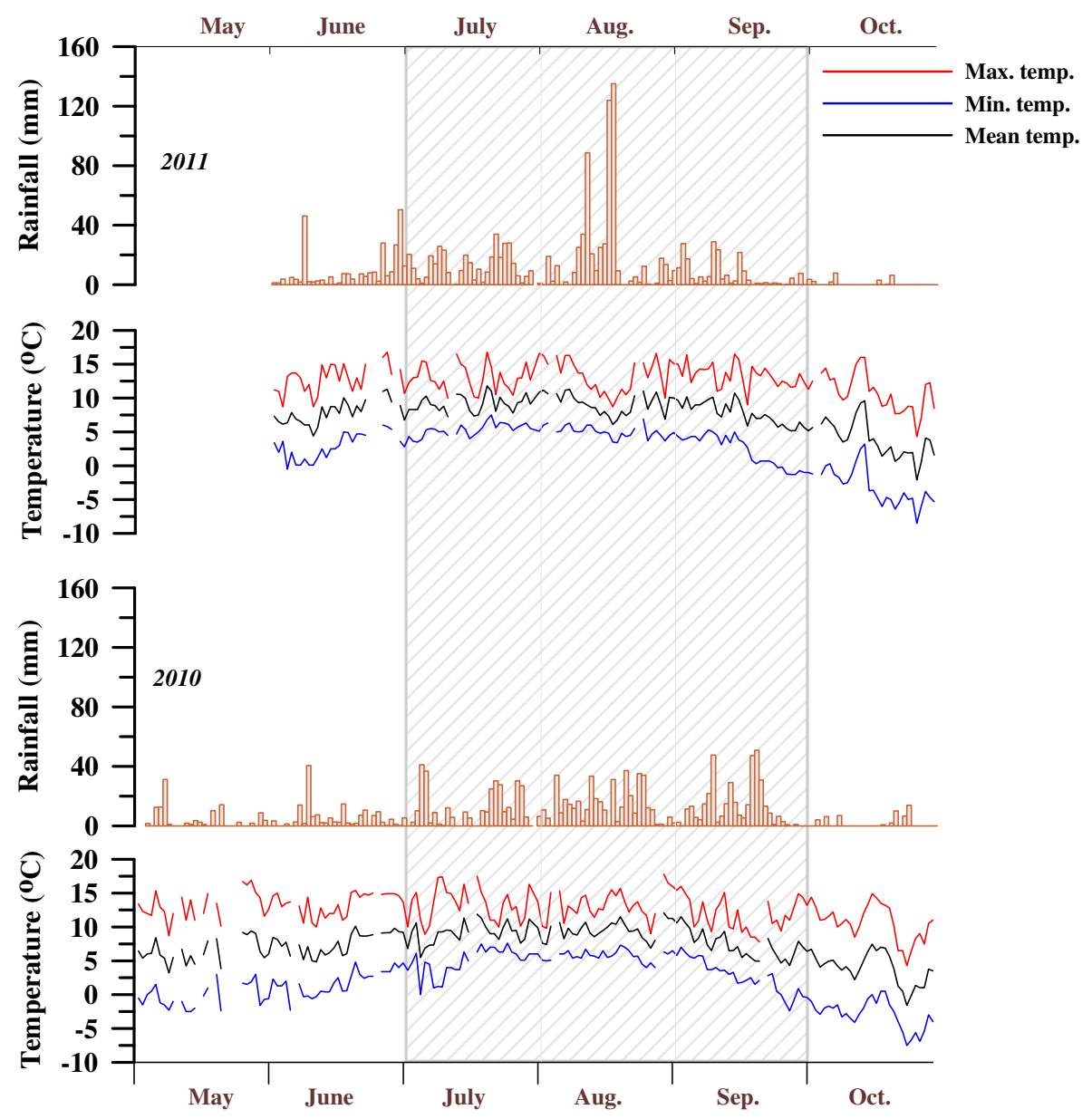

Figure 4. Daily maximum and minimum temperature and rainfall observed at Dokriani Glacier during the melting season of 2010 and 2011. 
Table 3. Temperature and rainfall distribution at Dokriani Glacier for 1995-1998 and 2010-2011.

\begin{tabular}{|c|c|c|c|c|c|c|c|c|c|}
\hline \multirow{2}{*}{$\frac{\text { Temp. }\left({ }^{\circ} \mathrm{C}\right)}{\text { Years }}$} & \multicolumn{2}{|c|}{ Maximum } & \multicolumn{2}{|c|}{ Minimum } & \multicolumn{2}{|c|}{ Mean } & \multirow[b]{2}{*}{ Years } & \multicolumn{2}{|c|}{ Rainfall (mm) } \\
\hline & 1995-1998* & 2010-2011 & 1995-1998* & $2010-2011$ & 1995-1998* & 2010-2011 & & 1995-1998* & 2010-2011 \\
\hline June & 12.8 & 13.2 & 4.4 & 2.3 & 9.5 & 7.8 & June & 186 & 207 \\
\hline July & 12.8 & 13.2 & 7.9 & 5.1 & 10.5 & 9.1 & July & 245 & 358 \\
\hline August & 12.8 & 13.3 & 7 & 5.4 & 9.7 & 9.3 & August & 376 & 519 \\
\hline September & 10.8 & 12.6 & 3.3 & 2.5 & 8.5 & 7.6 & September & 234 & 286 \\
\hline Average & 12.3 & 13 & 5.7 & 3.8 & 9.5 & 8.4 & Total & 1041 & 1370 \\
\hline
\end{tabular}

*Singh and Ramasastri (1999).

1996, 1997 and 1998 (Singh and Ramasastri 1999), respectively as compared to the peak intensity of 21.0 and $27.5 \mathrm{~mm} / \mathrm{hr}$ for 2010 and 2011, respectively (TRMM derived plots of rainfall intensity, figure 5).

\subsection{Air temperature $(T)$}

Mountain systems are sensitive to climate change and temperature trends in the Himalayan region show that temperature increases are greater in the uplands than lowlands (Shrestha et al. 1999).

Mean monthly maximum and minimum temperature over Dokriani Glacier for the years 2010 and 2011 were $13.2,13.2,13.3,12.6$ and $10.7^{\circ} \mathrm{C}$ and $2.3,5.1,5.4,2.5$ and $-3.0^{\circ} \mathrm{C}$ during the months of June-October, respectively. The mean monthly maximum and minimum temperatures were highest in August followed by July. The same trend was observed for average temperature and the mean monthly average temperatures were $7.8,9.1,9.3,7.6$ and $3.9^{\circ} \mathrm{C}$ during the months of June-October, respectively. Daily variations in maximum, minimum and mean temperature are illustrated in figure 4 . The mean monthly maximum, minimum and average temperatures for 1995-1998 and 2010-2011 are given in table 3. It is observed that while the maximum temperature rose by about $0.5^{\circ} \mathrm{C}$, the minimum and mean temperature declined by $2^{\circ}$ and $1^{\circ} \mathrm{C}$, respectively for 2010-2011 as compared to 19951998. This could be one of the factors affecting the variations in discharge, suspended sediment, amount and intensity of rainfall in 2010-2011 as against 1995-1998.

\subsection{Discharge (Q) and suspended sediment concentration (SSC)}

Glacier melt runoff represents the integrated basin response to various climatic inputs, with precipitation and temperature being the most important (Haritashya et al. 2006).

Hydrological data at Dokriani Glacier is only available for months from May to mid August, for the years 2010 and 2011. This is due to the fact that flash floods occurred at the gauging site between 15th and 25th August in 2010 and 2011, which washed out the discharge site. The major reason for the occurrence of these flash floods was continuous rainfall during the year 2010, in which a particular rainstorm lasted for 7 days (17th to 24th August) accounting for $182.2 \mathrm{~mm}$ of rainfall along with maximum SSC of 8178.1 and $9798.2 \mathrm{mg} / \mathrm{l}$, while in 2011 high intensity rainfall took place for 2 days (16th and 17th August) accounting for approximately $259 \mathrm{~mm}$ rainfall along with high SSC of $3270.6 \mathrm{mg} / \mathrm{l}$.

In order to study the variability of discharge and SSC, the data has been compared with previously recorded data (1995-1998), at the same discharge site (Singh and Ramasastri 1999). The discharge shows increasing trend from May, reaches its highest value in July and then starts reducing. The distribution of daily discharge and SSC for the available data of Dokriani Glacier are given in figure 6 . The mean monthly discharge observed during months of May, June, July, and August were $0.6,1.2,4.9$ and $7.9 \mathrm{~m}^{3} / \mathrm{s}$ and $3.6,7.7$ and $9.0 \mathrm{~m}^{3} / \mathrm{s}$ for June, July and August for the years 2010 and 2011, respectively. Average discharge was found to be $5.7 \mathrm{~m}^{3} / \mathrm{s}$ for the years 2010-2011 against $10.0 \mathrm{~m}^{3} / \mathrm{s}$ for $1995-1998$ (table 4 ).

In comparison to 1995-1998, higher SSCs were found in the present study (figure 7). The mean monthly SSCs for the period June-September were 1499, 2303, 3845 and $1649 \mathrm{mg} / \mathrm{l}$ for $2010-2011$ as compared to 452, 934, 965 and $275 \mathrm{mg} / \mathrm{l}$ for $1995-$ 1998. The maximum SSC for both the periods is in August followed by July. The mean SSCs for the melt season (June-September) for the periods 1995-1998 and 2010-2011 are 656 and $2324 \mathrm{mg} / \mathrm{l}$, respectively (table 4 ).

\section{Discussion}

Erosion in the Himalayan region is mainly controlled by the intensity of the Indian Summer Monsoon, but short lasting events can be responsible for more than half of the suspended 


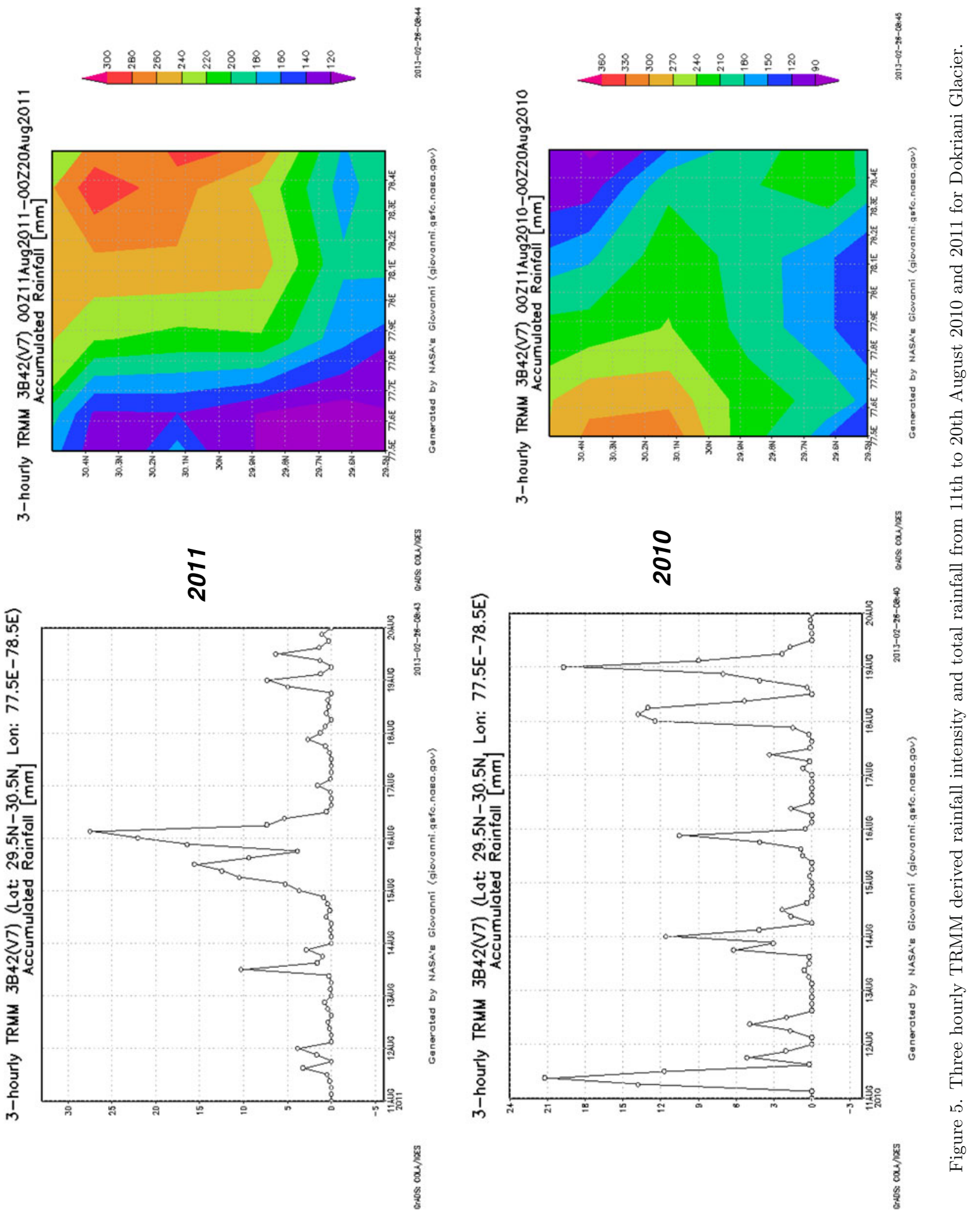


sediment transported by the rivers. The variability can be attributed to changes in discharge, precipitation rates and intensity, vegetation cover, geology/lithology of the region as well as seismic activity. There are numerous instances of recent disasters caused by heavy rainfall in the hilly terrains of the Himalayas.

It may be noted that though the discharge has decreased considerably in 2010-2011 as compared to 1995-1998, the SSC has increased four folds. Temperature plays an important role in meltwater generation and sediment transfer. Also the rise in temperature in the days immediately after the snowfall events of June 8 and September 16, 2010 caused the fresh snow to melt and therefore mobilised the sediment, while the decrease in discharge during 2010-2011 as compared to 1995-1998 could be due to the fact that the overall mean and minimum temperatures had decreased in the basin. The increased rainfall intensity could be attributed to the changes in temperature (maximum, minimum and mean).

The increased intensity of rainfall during 20102011 is a significant factor for the cause of flash flood and high suspended sediment concentrations. The high intensity rainfall mobilises a large amount of sediment from the deglaciated area near the snout. Another important factor is the mobilisation of sediment from the glacier surface in the ablation zone as well as debris flow/landslides from valley walls and unstable lateral moraines (figure 2c), which erode under the influence of high intensity rainfall events and act as a major source for suspended sediment. It has been established that high intensity rain increases the scouring capacity by 4 times, the carrying capacity by 32 times

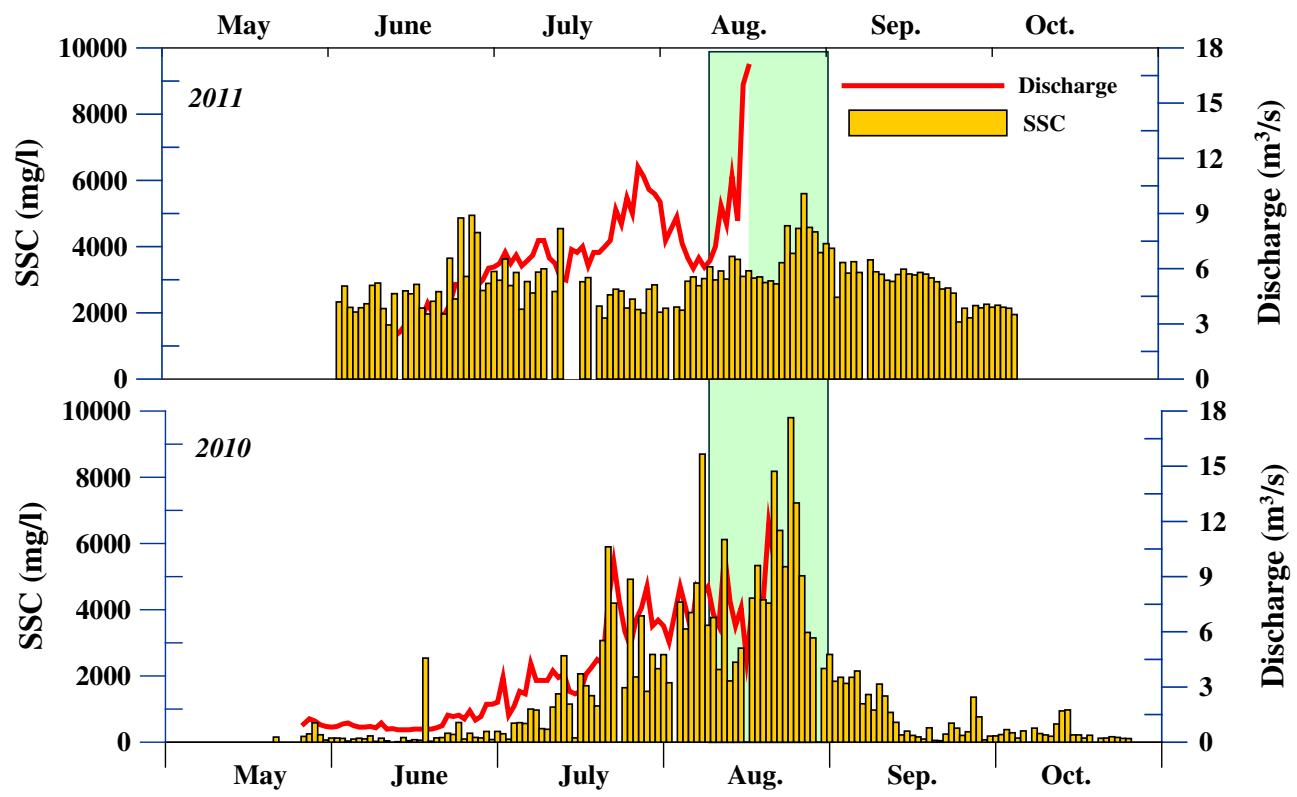

Figure 6. Discharge and SSC at Dokriani Glacier during the ablation season of 2010 and 2011.

Table 4. Observed discharge and SSC at Dokriani Glacier for 1995-1998 and 2010-2011.

\begin{tabular}{|c|c|c|c|c|c|c|c|c|}
\hline & 1995 & 1996 & 1997 & 1998 & 1995-1998* & 2010 & 2011 & 2010-2011 \\
\hline \multicolumn{9}{|l|}{$\mathrm{Q}\left(\mathrm{m}^{3} / \mathrm{s}\right)$} \\
\hline June & 7.2 & 6.5 & 6.5 & 4.2 & 6.1 & 1.2 & 3.6 & 2.4 \\
\hline July & 13.0 & 11.2 & 10.0 & 7.0 & 10.3 & 4.9 & 7.7 & 6.3 \\
\hline August & 10.9 & 11.1 & 24.2 & 7.6 & 13.5 & 7.9 & 9.0 & 8.4 \\
\hline Average & 10.4 & 9.6 & 13.6 & 6.3 & 10.0 & 4.6 & 6.8 & 5.7 \\
\hline \multicolumn{9}{|l|}{$\mathrm{SSC}(\mathrm{mg} / \mathrm{l})$} \\
\hline June & 289 & 851 & 444 & 225 & 452 & 233 & 2766 & 1499 \\
\hline July & 819 & 1046 & 1269 & 600 & 934 & 1929 & 2677 & 2303 \\
\hline August & 985 & 1014 & 1164 & 696 & 965 & 4226 & 3464 & 3845 \\
\hline September & - & - & 275 & 275 & 275 & 576 & 2723 & 1649 \\
\hline Average & 698 & 970 & 788 & 449 & 656 & 741 & 2907 & 2324 \\
\hline
\end{tabular}

*Singh and Ramasastri (1999). 


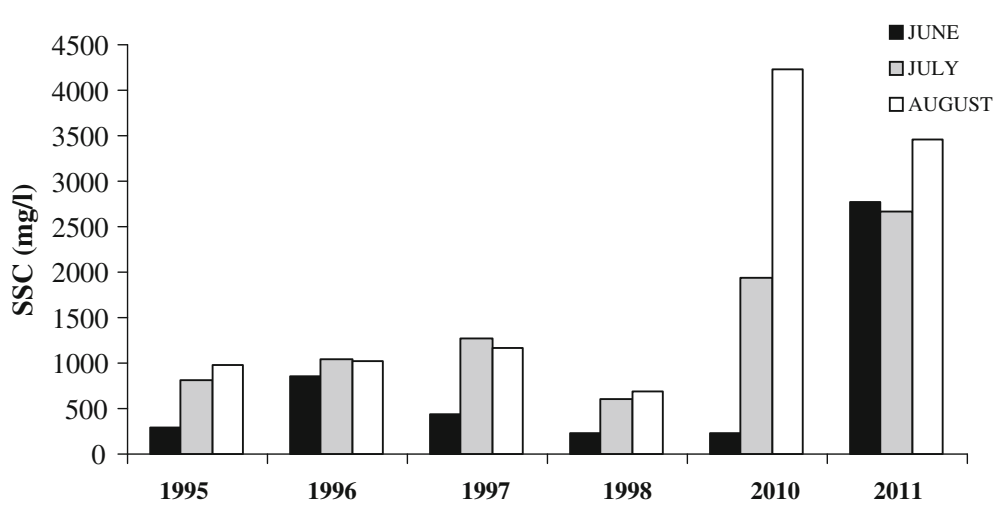

Figure 7. SSC observed near the snout of Dokriani Glacier.
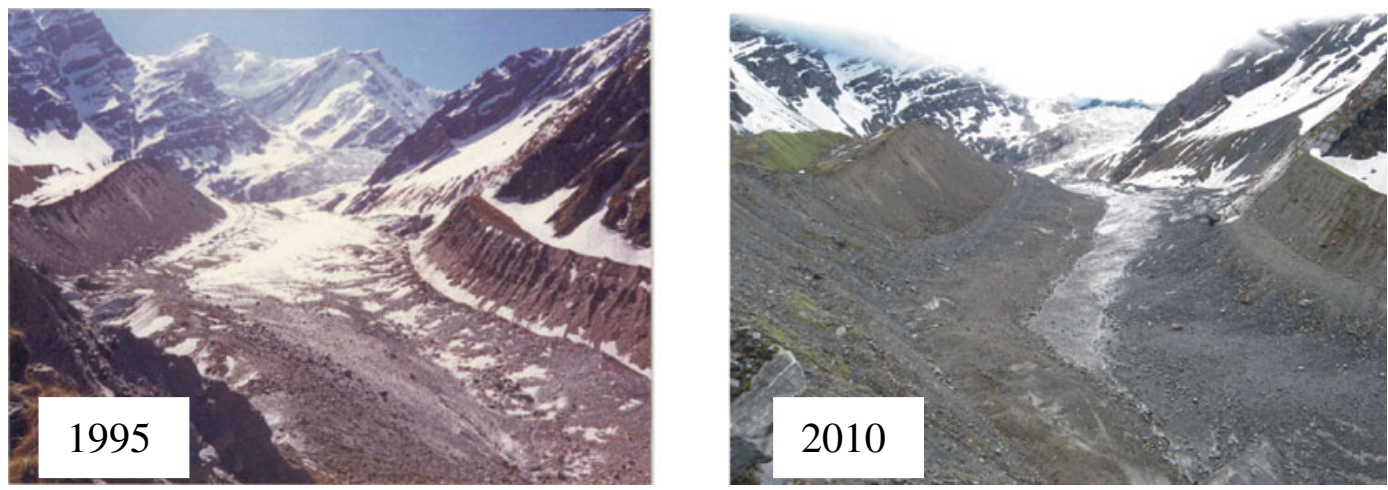

Figure 8. Synoptic view of deglaciated area of Dokriani Glacier since 1995 to 2010.

and particle size carried by 64 times (Tempany and Grist 1958). Though the debris cover has not been quantified in the present study due to small basin area and lack of high resolution satellite data, there is photographic evidence of increasing debris cover and deglaciation over Dokriani Glacier (figure 8). Further studies should concentrate on better characterization of sediment flux within the basin in order to improve our understanding of dynamics at the basin scale. It would provide useful information on suspended sediment behaviour across river basins and contribute to improve sediment transfer models.

The threat to lives and property posed by severe storms highlights the immediate need to establish a good network of Automatic Weather Stations and hydrological monitoring in mountainous regions. Long-term records would provide more accurate representations of hazard zonation and frequency of events in mountainous areas. Also validation of remotely sensed data such as that of TRMM with field observations may be very useful in the future for getting meteorological data (temperature, rainfall, etc.) of remote places. An approach using field data from monitoring sites in combination with remote sensing is essential in high mountain hazard management and disaster mapping. The identification and monitoring of such hazardous sites can at least predict the probable area of occurrence of future disasters.

\section{Acknowledgements}

Authors are grateful to the Director, Wadia Institute of Himalayan Geology, Dehra Dun, for providing necessary facilities to carry out the present work. They also thank their colleagues and support-staff from Centre for Glaciology for their help and co-operation on the field and in the laboratory. The TRMM rainfall data used in this study has been acquired using the GES-DISC interactive online visualization and analysis infrastructure (Giovanni) as part of NASA's Goddard Earth Sciences (GES) Data and Information Service Centre (DISC). They would also like to thank Department of Science and Technology for supporting this study.

\section{References}

Ali K F, Dirk H and Boer De 2007 Spatial patterns and variation of suspended sediment yield in the upper Indus river basin, northern Pakistan; J. Hydrol. 334 368-387.

Azam M F, Wagnon P, Ramanathan A, Vincent C, Sharma P, Arnaud Y, Linda A, Pottakkal J G, Chevallier P, Singh 
V B and Berthier E 2012 From balance to imbalance: A shift in the dynamic behaviour of Chhota Shigri Glacier, Western Himalaya, India; J. Glaciol. 58(208) 315-324.

Berthier E and Vincent C 2012 Relative contribution of surface mass-balance and ice-flux changes to the accelerated thinning of Mer de Glace, French Alps, over 1979-2008; J. Glaciol. 58(209) 501-512.

Bhambri R, Bolch T, Chaujar R K and Kulshreshtha S C 2011 Glacier changes in the Garhwal Himalayas, India during the last 40 years based on remote sensing data; J. Glaciol. 57203.

Bhutiyani M R 2000 Sediment load characteristics of a proglacial stream of Siachen Glacier and the erosion rate in Nubra valley in the Karakoram Himalayas, India; J. Hydrol. 227 84-92.

Bolch T, Buchroithner M F, Kunert A and Kamp U 2007 Automated delineation of debris-covered glaciers based on ASTER data; Geoinformation in Europe, Proceedings of 27th EARSeL Symposium, pp. 403-410.

Collins D N 1996 Sediment transport from Glacirised basins in the Karakoram Mountains. Erosion and sediment yield: Global and regional perspectives; Proceedings of the Exeter Symposium, IAHS Publication 236 85-96.

Dobhal D P and Mehta M 2010 Surface morphology, elevation changes and terminus retreat of Dokriani Glacier Garhwal Himalaya: Implication for climate change; Him. Geol. 31(1) 71-78.

Gardelle J, Berthier E and Arnaud Y 2012 Slight mass gain of Karakoram glaciers in the early twenty-first century; Nature Geosci. 5 322-325.

Gupta V and Bist K S 2004 The 23 September 2003 Varunavat Parvat landslide in Uttarkashi township, Uttaranchal; Curr. Sci. 87(11) 1600-1605.

Gurnell A M, Clark M J, Hill C T and Greenhalgh J 1992 Reliability and representativeness of a suspended sediment concentration monitoring programme for a remote alpine proglacial river; In: Erosion and Sediment Transport Monitoring in River Basins (eds) Bogen J, Walling D E and Day T, Proceedings of the Oslo Symposium 24-28 August 1992, Int. Assoc. Hydrol. Sci. Publ. 210 191-200.

Haeberli W, Beniston M 1998 Climate change and its impacts on glaciers and permafrost in the Alps; Ambio 27 258-265.

Haritashya U K, Kumar A and Singh P 2010 Particle size characteristics of suspended sediment transported in meltwater from the Gangotri Glacier, Central Himalaya An indicator of subglacial sediment evacuation; Geomorphology 122 140-152.

Haritashya U K, Singh P, Kumar N and Gupta R P 2006 Suspended sediment from the Gangotri Glacier: Quantification, variability and associations with discharge and air temperature; J. Hydrol. 321 116-130.

Hasnain S I and Thayyen R J 1999 Discharge and suspendedsediment concentration of meltwaters, draining from the Dokriani Glacier, Garhwal Himalaya, India; J. Hydrol. 218 191-198.

Hewitt K 2005 The Karakoram Anomaly? Glacier expansion and the 'elevation effect' Karakoram Himalaya; Mountain Res. Dev. 25(4) 332-340.

Jain S K, Singh P, Saraf A K and Seth S M 2003 Estimation of sediment yield for a rain, snow and glacier fed river in the Western Himalayan region; Water Resourc. Manag. 17 377-393.

Kumar K, Miral M S, Joshi V and Panda Y S 2002 Discharge and suspended sediment in the meltwater of Gangotri Glacier, Garhwal Himalaya, India; Hydrol. Sci. J. 47(4) 611-619.
Kumar K V, Bhattacharya A, Martha T R and Bhasker P V 2003 Cloud Phata Buyang, Uttaranchal landslide be prevented? Curr. Sci. 85 707-708.

Mazari R K and Sah M P 2004 Puliya Nal cloudburst of July 16, 2003, District Kullu, Himachal Pradesh: Lesson for policy implementation; Him. Geol. 25 153-161.

Meier M F, Dyurgerov M B and McCabe G J 2003 The health of glaciers: Recent changes in glacier regime; Clim. Change 59(1-2) 123-135.

Naithani A K, Joshi V and Prasad C 2002 Investigation on the impact of cloudburst in the Tehri District, Uttaranchal; J. Geol. Soc. India 60 573-578.

Nuimura T, Fujita K, Yamaguchi S and Sharma R R 2012 Elevation changes of glaciers revealed by multitemporal digital elevation models calibrated by GPS survey in the Khumbu region, Nepal Himalaya, 1992-2008; J. Glaciol. 58(210) 648-656.

Ostrem G 1975 Sediment transport in glacial meltwater streams; In: Glaciofluvial and glaciolacustrine sedimentation (eds) Jopling A V, McDonald B C and Tulsa O K, Society of Economic Paleontologists and Mineralogists, Spec. Publ. 23 101-122.

Owen L, Derbyshire E and Scott C 2003 Contemporary sediment production and transfer in high-altitude glaciers; Sedim. Geol. 155(1-2) 13-36.

Pandey S K, Singh A K and Hasnain S I 2002 Grain-size distribution, morphoscopy and element chemistry of suspended sediments of Pindari Glacier, Kumaon Himalaya, India; Hydrol. Sci. J. 2 213-226.

Ramanathan A L 2011 Status Report on Chhota Shigri Glacier (Himachal Pradesh), Department of Science and Technology, Ministry of Science and Technology, New Delhi, Himalayan Glaciology Technical Report No.1, pp. 56-59.

Rana N, Sundriyal Y P and Juyal N 2012 Recent cloudburst induced landslides around Okhimath, Uttarakhand; Curr. Sci. 103(12) 1389-1390.

Rautela P and Paul S K 2001 August 1998 landslide tragedies of central Himalayas (India): Learning from experience; Int. J. Environ. Studies 58 343-355.

Sah M P, Asthana A K L and Rawat B S 2003 Cloud burst of August 10, 2002 and related landslides and debris flows around Budha Kedar (Thati Kathur) in Balganga valley, district Tehri; Him. Geol. 24 87-101.

Sarkar S and Kanungo D P 2010 Landslide disaster on Berinag-Munsiyari Road, Pithoragarh District, Uttarakhand; Curr. Sci. 98(7) 900-902.

Sati S P, Sundriyal Y P, Rawat G S and Juyal N 2006 Some observations on slope instability in Uttaranchal Himalaya; ISG Newsletter 12(3-4) 49-56.

Sati S P, Sundriyal Y P, Rana N and Dangwal S 2011 Recent landslides in Uttarakhand: Nature's fury or human folly; Curr. Sci. 100(11) 1617-1620.

Scherler D, Bookhagen B and Strecker M R 2011 Spatially variable response of Himalayan glaciers to climate change affected by debris cover; Nature Geosci. 4 1-4.

Shrestha A B, Wake C P, Mayewski P A and Dibb J E 1999 Maximum temperature trends in the Himalaya and its vicinity: An analysis based on temperature records from Nepal for the period 1971-1994; J. Climate 12 2775-2787.

Singh P and Ramasastri K S 1999 Temporal distribution of Dokriani Glacier melt runoff and its relationship with meteorological parameters; DST National Institute of Hydrology: Roorkee, Project report submitted to DST, Govt. of India.

Singh P, Ramasastri K S, Kumar N and Bhatnagar N K 2003 Suspended sediment transport from the Dokriani Glacier in the Garhwal Himalayas; Nordic Hydrology 34 $221-244$. 
Singh P, Haritashya U K, Ramasastri K S and Kumar N 2005 Diurnal variations in discharge and suspended sediment concentration, including runoff-delaying characteristics, of the Gangotri Glacier in the Garhwal Himalayas; Hydrol. Process. 19 1445-1457.

Singh P, Haritashya U K and Kumar N 2007 Meteorological study for Gangotri Glacier and its comparison with other high altitude meteorological stations in central Himalayan region; Nordic Hydrology 38 59-77.

Singh P, Kumar A and Kishore N 2010a Meltwater storage and delaying characteristics of Gangotri Glacier (Indian Himalayas) during ablation season; Hydrol. Process. 25 159-166.

Singh V B, Ramanathan A L, Pottakkal J G, Sharma P, Linda A, Azam F M and Chatterjee C 2012 Chemical characterisation of meltwater draining from Gangotri glacier, Garhwal Himalaya, India; J. Earth Syst. Sci. 121(3) 625-636.

Tempany H and Grist D H 1958 Introduction to tropical agriculture; Longmans, London.

Thakur V C 2000 Cloudburst floods and flash floods caused by landslide and debris flow dam failures in the Indian Himalayas; ICIMOD Newsletter 38 20-22.

Thayyen R J, Gergan J T and Dobhal D P 2005 Monsoonal control on glacier discharge and hydrographic characteristics: A case study of Dokriani glacier, Garhwal Himalaya, India; J. Hydrol. 306 37-49.

Thayyen R J, Dimri A P, Kumar P and Agnihotri G 2013 Study of cloudburst and flash floods around Leh, India, during August 4-6, 2010; Natural Hazards 65 2175-2204. 